\title{
Modernization of Public Administration and e-Government in Bulgaria
}

\author{
Zwetelina Gankova-Ivanova \\ Technical University - Gabrovo, Bulgaria
} \begin{abstract}
contributes to achieving the following strategic objectives: integration.

I INTRODUCTION

This document pays attention to the architecture of the portal infrastructure of the e-Government in Bulgaria. The interoperability in it is analyzed, as well as the need of existence of common standards when dealing with electronic documents. The preconditions for this are given by the National Framework for interoperability of the information systems.

Based on the analyses done, it is concluded that Bulgaria has a consistent policy of modernizing its administration. The basis for this is the existing legislative framework. However, it is said that in comparison with other EU countries the implementation of the e-Government in Bulgaria is lagging behind. The reasons for the weaknesses in the implementation of the e-Government in Bulgaria are discussed and measures for overcoming the backlog are proposed.
\end{abstract}

Abstract. The present paper discusses current issues related to administration and government that affect e-Governance and e-Government. It considers the strategic document addressing the modernization of the Bulgarian state administration and the improvement of the judicial system functioning, as well as the implementation of e-Government in Bulgaria - the Operational Programme "Administrative Capacity". It is part of the National Strategic Reference Framework 2007 - 2013 and

1. Enhancing economic competitiveness in terms of high and stable economic growth;

2. Stimulation of human potential by ensuring intensive employment, higher incomes and social

The Operational Programme has a horizontal nature and its purpose is to improve the operation of public administration directed to implementation of effective policies and quality services to citizens and businesses and creating conditions for sustained economic growth and employment, increasing professionalism and transparency, improving the functioning of the judiciary.

On this basis, the priorities of the Operational Programme for achieving the strategic goals of modern administration - quality services and e-Governance - are considered.

\section{OP "Administrative}

Capacity" - a key tool for realizing e-government in Bulgaria

OP "Administrative Capacity" is the strategic document of the Government of Bulgaria, which is the basis of modernization of the Bulgarian state administration and aims to improve the operation of the legal system and structures of civil society for the period 2007 - 2013. It is funded by European Social Fund (ESF) and the national budget. The program line with the recommendations of the Strategic Guidelines for Community cohesion to undertake special action for strengthening of the administrative capacity under the "Convergence".
OP "Administrative Capacity" has a horizontal scope, and its strategic goal is:

Improving the functioning of state administration to implement effective policies, quality services for citizens and businesses, and creating conditions for sustainable economic growth and employment. Enhancing the professionalism, transparency and accountability in the judiciary.

The Programme has the following specific objectives:

- Effective functioning of the administration and judiciary;

- Improving human resources management and qualification improvement of public officials, judiciary and structures of civil society;

- Modern service provided by the administration and the judiciary.

By fulfilling of the OP "Administrative Capacity" will be accomplished common standards and rules for public administration reform at all levels - central, regional and local. It shall be developed professional administration aimed at the needs of society and reduce the cost and bureaucratic procedures in its operations. The Programme will also implement effective mechanisms for internal and external controls for greater accountability and transparency. The capacity of civil society cooperation and dialogue with the administration and the judiciary will also be supported within The Programme. This will ensure efficient formulation and implementation of policies in implementing the principle of partnership.

Besides its horizontal scope The Programme has and sectoral scope, as it addresses the reform of the judiciary with focusing in transparency in its work and development of human resources. Strengthening of the 
judiciary is essential for the implementation of Community law. Effective and transparent judicial system is an important precondition for creating a good environment for business and higher economic growth. In addition the opportunities of transnational and interregional cooperation will be used for the exchange of best practices with other Member States in areas of importance to the administrative and judicial reform.

To achieve its objectives, The Programme is concentrated in the following priority areas:

Axis I: Good Governance

Axis II: Human Resource Management

\section{Axis III: Quality administrative service and development of e-Government}

Axis IV: Technical Assistance

In the developing The Programme are considered the main strategic documents of the European Union (EU), the national policy priorities and the National Reform Programme.

Indicative Financial Framework 2007 - 2013

$\Gamma$.

- Total budget of the OPAC 2007 - 2013 years: 181 million

- $\mathbf{3 . 5 \%}$ of total aid is from the Structural Funds and $\mathbf{1 3 \%}$ is from the European Social Fund

- Ratio of EU funds / national co-financing: $154 / 27$ million $(85 / 15 \%)$

Programme priority axes

- Priority AxisI "Good Governance" - 24\% of the total budget for The Programme

- Priority Axis II "Human Resources" - 41\% of the total budget for The Programme

- Priority Axis III "Quality administrative service delivery and development of egovernment" - $31 \%$ of the total budget for The Programme

- Priority Axis IV "Technical assistance" - 4\% of the total budget for The Programme

\section{E-Government}

The e-Government is a modern way of working the state administration through the use of informational and communicational technologies (ICTs). It's a tool for improving the administrative services, the increase of efficiency of public administration and optimization of costs.

The development of e-governance improves transparency in the administration and accessibility of services. It reduces the time and effort of citizens and businesses in their communication with the administration. The e-Government covers four major groups of relations (communication and services): administration - citizens, administration - business, administration - administration, administration employees.

There is already an overall concept for developing an e-Government in Bulgaria.
It's been noticed in Bulgaria a lagging behind the EU Member States in the field of building an egovernment. Analysis of the reasons for it allows the identification of measures for its development to a level meeting the European requirements. Until now there could be four major reasons for the inadequate development of e-Government in Bulgaria: lack of appropriate legal basis, lack of interoperability of the information systems administration, lack of adequate electronic exchange, as well as unsolved problem of data unification.

Improvement of the basic legal and strategic basis for developing of e-governance

An important element of the development of the egovernment is the adoption of legal documents related to implementation, application and exploitation of ICTs (strategies, plans, architectures, description of work processes, procedures, rules and regulations). They also provide determination and coherence of the administration in the field of e-Government.

In 2006 was completed successfully the implementation of e-Government Strategy, 20022006, which determines the purposes and principles of development of information systems related to the services provided by public administration and the general environment for information technology in the administration of Bulgaria. We are currently preparing a new strategy for e-government and a roadmap to it. These documents will be adopted at the end of 2007. To ensure sustainable implementation of projects in the field of e-government it should also be established a comprehensive framework for their long-term financing.

A Law for the e-Government was accepted by the National Assembly on 30.05.2007. It regulates the administrative service delivery for citizens and businesses by electronic means: actions when working with electronic documents in one administration and exchange of electronic documents between public authorities. With this law the delivery of public services electronically will become mandatory for all administrative structures and for persons performing public functions (notaries, state and municipal schools, etc.), and for organizations providing public services (education, health, district heating and telecommunications, postal, etc.).

\section{E-Government in Bulgaria}

Since the end of 2007 the country is implementing the "Integrated administrative services at central and local level and providing public services", which contractor is the Ministry of State Administration and Administrative Reform (Ministry of State Administration). The project objective is providing Internet access to quality services for the organizations and citizens, including citizens with disabilities, and integrating information systems administration.

The project, called "Electronic Government" or "Electronic Governance", is using modern information and communication technologies. They are used for building an integration environment to which it will 
gradually be connected information systems of all government administrations at central and local level, as well as providers of public services (education, health, electricity, district heating, etc.). This will enable the exchange of operational information and services electronically among all providers of administrative and public services.

Thanks to this project, citizens and businesses will receive both new electronic services and simplified electronic versions of existing public services, with a significantly reduced number of documents required for declaring them and with greater transparency and improved control over their implementation. And most importantly - will not be necessary for applicants to visit the private service provider. E-services will may be made 24 hours a day, 7 days a week, 365 days a year.

For users of electronic services - citizens, businesses and other organizations - the face of "eGovernment" will be a single portal for access to the electronic services. The portal is part of the integrated e-Government environment and it will be publicly available on the Internet. Through it users of administrative services shall communicate with service providers - will declare their service, will send and receive electronic documents and messages. When the nature of the service allows, its results will be received as an electronic document signed with digital signature of the provider. If the supplier requires it, users will need to use digital signature in order to identify in applying for electronic administrative services. There will be a range of services that will require identification by digital signature in its declaring.

The pilot start of the program became a fact on 1 February 2010, starting with 14 electronic services via the government portal. Integrated platform for Internet services started in test mode, which will continue for at least 4 months. The aim is to launch 15 more electronic services by March and by the end of the year to reach 100 .

The prototype of the portal is the so called "One stop shop". This service model allows citizens and organizations to:

- $\quad$ have quick and easy access to institutions;

- $\quad$ to reduce the time for service;

- $\quad$ to reduce contact between applicants and employees, which will help to reduce bad practices.

The places that need to be "visited" in this service model are reduced to one, and required documents, which must be presented by the applicant are minimized (Figure 1).

The single portal for access to the electronic services is a result of mixing model for one-stop shop with information and communication technology and electronic processing of documents.

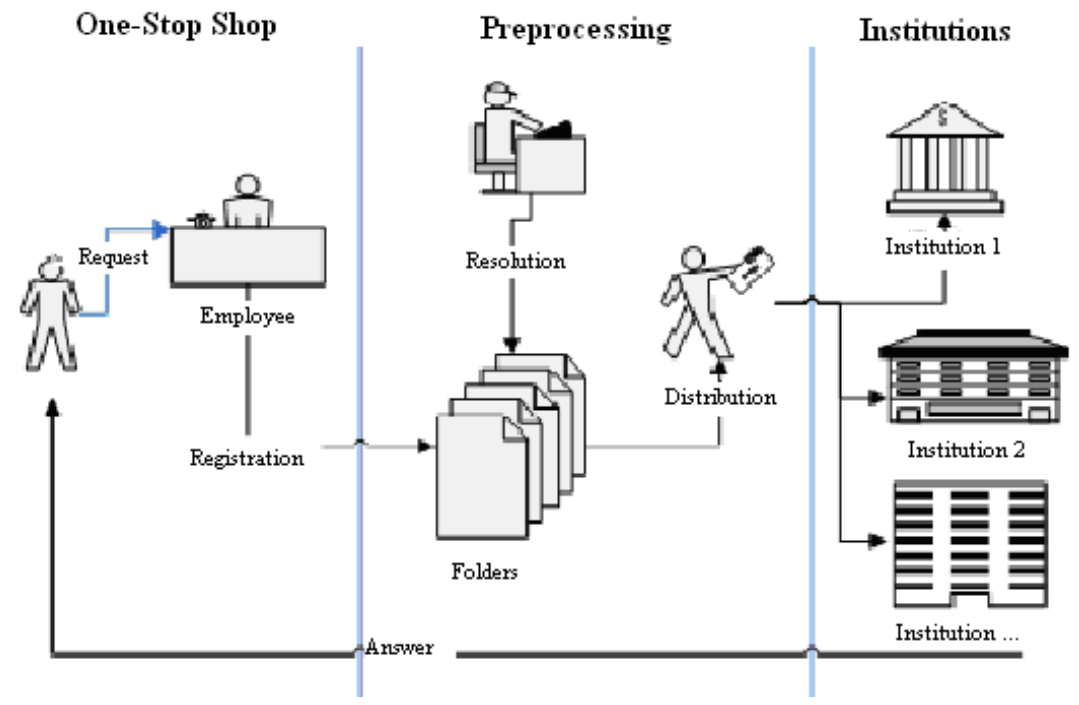

Figure 1: One- stop shop

The portal inherits the advantages of the model of one-stop shops and the opportunities of the technologies, used in information processing. The result is an environment that has great potential for development and interaction with other systems (Figure 2). 


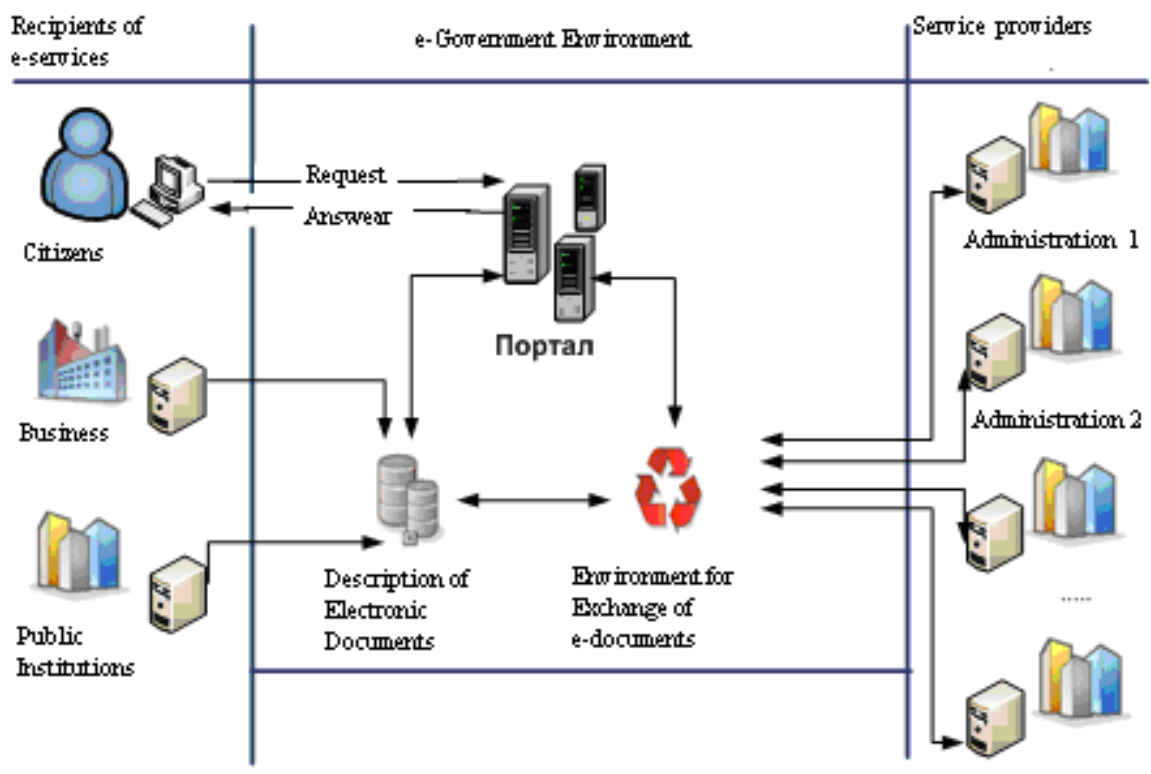

Figure 2

Access to e-services via the portal will be free, unlimited and unconditioned by any requirements for user authentication. In other words, users can use the portal without introducing name and password, i.e. as anonymous users.

\subsection{Interoperability}

A major problem in the implementation of $\mathrm{e}$ governance is the need for interoperability, common standards and rules for handling electronic documents.

In 2006 the government adopted a National Framework for interoperability of the information systems executive. It includes the establishment of a Register of standards to ensure interoperability, Register of information objects and Register of electronic services. An Instruction on the procedures for certification of systems according to European standards was approved. This provides interoperability to information systems to the departments in providing e-services. National Interoperability Framework is a document that allows Bulgaria to meet the integration of national systems of Member States of the European Union to organize cross-border electronic services. Bulgaria will comply with the European Interoperability Framework.

The implementation of centralized integrated system of the e-Government is yet to be done. It aims to serve as integrated environment for existing independent information systems in public administration and will be the basis of the integrated environment for document exchange. It is developed and a pilot integrated system for e-field, which will integrate the information systems of local and regional level.

With the implementation of the two projects will be constructed a unified information environment for providing electronic services from the central, regional and municipal administrations. They provide electronic exchange of documents for performing the requested services between all departments of central and local administrations. With their implementation will be created a technological environment that will provide:

- Single point of access to all electronic services at any time and from anywhere;

- Online description of all administrative services;

- Simplified user-friendly interface for ordering services, including for disadvantaged people;

- Unified design of the portals of all regional and municipal administrations by creating uniform standards;

- Opportunity for citizens and businesses to electronically track the progress of implementation of the services they have ordered.

\section{CONCLUSION}

With regard to its commitments to modernize the public administration in Bulgaria is pursue a consistent policy. The basis for this legal framework is already established. However, it should be noted that in comparison with other Member States of the European Union Bulgaria has a delay in the use of electronic governance and e-Government. Analysis of the reasons for this allows measures to be taken to ensure that European requirements will be met.

Until now there have been established four main reasons for weaknesses in the implementation of egovernment in Bulgaria:

- Lack of efficiently functioning legal base;

- Lack of interoperability of information systems in the administration;

- Lack of adequate electronic document workflow between administrative departments;

- Unresolved problems with unification of the information for administrations. 


\section{REFERENCES}

[1] Bulgaria: ICT Infrastructure and E-Readiness Assessment, ARC Fund, 2002

[2] E-Europe 2005: An information society for all, An Action Plan to be presented in view of the Sevilla European Council, 2002

[3] E-Government: Presentation of the Status and development of e-Government in Bulgaria, Coordination center for information, communication and administration technologies, Sofia

[4] Operative Programme "Administrative capacity" 2007 - 2013, Ministry for State Administration and Adminisrative reform, Sofia

[5] Government Strategy for E-Government in Bulgaria

[6] Government Strategy for modernizing the state administration, 2002
[7] Obama 2009: Obama, Barack: Memorandum for the Heads of Executive Departments and Agencies SUBJECT: Transparency and Open Government, in: General Services Administration: Transparency and Open Government, Intergovernmental Solutions Division, GSA Office of Citizens Services and Communications, Washington DC 2009, S. 4

[8] Programm für Transparenz in der Staatsverwaltung und in der Tätigkeit der Personen im höheren Dienst http://www.mdaar.government.bg/programs.php

[9] Bericht über den Zustand der Verwaltung, 2006, S. 156 http://www.mdaar.government.bg/docs/ Annual\%20Report\%20\%202006_26.07.2007.pdf

[10] Bericht über das Programm für Transparenz in der Tätigkeit der staatlichen Verwalung und der Personen im höheren Dienst, zum Dezember 2006, S. 14, www.mdaar.government.bg/lucidity.php 